\title{
Prevalence and Drug Resistance Pattern of Escherichia coli Strains Isolated from Milk and Milk Products
}

\author{
Monika Soni $^{1 *}$, Abhishek Gaurav ${ }^{1}$, Bincy Joseph ${ }^{2}$, S. S. Shekhawat ${ }^{1}$ \\ and Subhash Chand Meena ${ }^{1}$ \\ ${ }^{1}$ Department of Veterinary Public Health, College of Veterinary and Animal Science, \\ Navania, Udaipur, India \\ ${ }^{2}$ Department of Veterinary Microbiology, College of Veterinary and Animal Science, \\ Navania, Udaipur, India \\ *Corresponding author
}

\section{A B S T R A C T}

\section{Keywords}

Escherichia coli,

Antibiotic

resistance,

Virulence,

Prevalence, Milk

\section{Article Info}

Accepted:

12 September 2019

Available Online:

10 October 2019
In the present study prevalence and antibiotic susceptibility pattern of Escherichia coli isolated from milk and milk products from retail dairies of different parts of Udaipur city, Rajasthan were determined. The phenotypic and genotypic characterization of $E$. coli isolates was done to determine its prevalence and antibiotic susceptibility pattern. A total of 150 samples comprising of raw pooled milk $(n=30)$, pasteurized milk $(n=30)$, dahi $(n=30)$, paneer $(n=30)$, and sweets (burfi) $(n=30)$ were processed for the isolation of $E$. coli. Out of 150 samples, the prevalence of $E$. coli was recorded in raw pooled milk, dahi, paneer, pasteurised milk and sweets (burfi) samples as 76.66\% (23), 33.33\% (10), 20\% (6), $0 \%(0)$ and $43.33 \%$ (13), respectively. The analysis of antibiogram revealed that the most effective antibiotic was Chloramphenicol $(91.30 \%)$, followed by Trimethoprim to which $86.95 \%$ of the isolates were sensitive. Also, $82.60 \%$ isolates were sensitive to Gentamicin and Ciprofloxacin, $78.26 \%$ to Ceftriaxone, $73.91 \%$ to Co-Trimoxazole and other antibiotics were still less effective. Penicillin-G showed highest resistance (100.00\%) followed by Methicillin (91.30\%), while $52.17 \%$ isolates were resistant to Ampicillin, $43.47 \%$ to Erythromycin and Carbenicillin, $21.73 \%$ to Tetracycline, $17.39 \%$ to Ceftriaxone and other antibiotics were still less resistant. Out of $50 \mathrm{E}$. coli isolates from milk and milk products, only 11 isolates $(22 \%)$ were found to be positive for $b l a_{C T X-M}$ gene while only 2 isolates $(1.25 \%)$ were found to be positive for stxl gene. These results indicate that the milk and milk products sold in the study area have high level of antibiotic resistant $E$ coli which is a public health concern. Therefore, stringent hygienic measures and prudent use of antibiotics should be practiced to improve the present worrisome situation.

\section{Introduction}

Milk is an extraordinarily nutritious food for bacterial growth, which not only spoils the milk and milk products but also can cause infections in consumers [1]. Raw milk contains many microorganisms, because it is regarded as perfect media for microbial 
growth [2]. Milk is highly prone to contamination and can serve as an efficient vehicle for human transmission of food borne pathogens, especially Gram-negative bacteria, as these are widely distributed in the environment [3]. Raw milk consumption by humans may be attributed to the lack of knowledge about the food borne pathogens in raw milk. Food borne pathogens are a major threat to food safety, especially in developing countries where hygiene and sanitation facilities are often poor. Escherichia coli is among the major cause of outbreaks of food borne diseases [4]. The majority of human infections occur due to the intake of contaminated raw milk products and unpasteurized milk which have been implicated in food borne outbreaks and in sporadic cases of human illness [5].

$E$ coli is a parasite living in human and animal intestine. It is among many pathogenic microorganisms which can enter into milk and milk products and is considered as a reliable indicator of contamination by manure, soil, and contaminated water [6,7]. Moreover, different food borne pathogens in milk may be introduced in milk due to the faecal contamination during milking process [8]. Consumption of hygienic foods causes more than 300 diseases worldwide $[9,10]$. Food borne diseases lead to around 80 million sicknesses, 330,000 hospitalizations, and 6000 deaths in the United States annually $[11,12]$.Therefore, consumption of raw milk may be linked with the incidence of foodpoisoning outbreaks [13]. Also, the emergence of multi drug resistant (MDR) isolates worldwide, pose an additional threat to human health [14].

Presence of $E$. coli in milk and milk products indicates the presence of enteropathogenic microorganisms which is a public health hazard [15]. Different E. coli pathotypes are responsible for causing intestinal and extra intestinal infections [16]. Ruminants are the main reservoir and the most significant source of access of STEC in the food chain [17]. Shiga (vero) toxin (Stx)-producing E.coli (STEC) is a part of a virulent group of E. coli known as enterohemorrhagic E. coli (EHEC) $[18,19]$. In humans, EHEC cause infections ranging from mild diarrhoea to lifethreatening problems, like hemorrhagic colitis and haemolytic uremic syndrome [20,21]. EHEC is linked with bloody diarrhoea and haemolytic uremic syndrome and expresses one or two Shiga-like toxin-encoding genes stx1 and stx2 [22]. Among all E. coli pathotypes, ETEC strains cause a cholera-like diarrhoeal disease and are the most common cause of childhood and travellers' diarrhoea in developing countries [23]. EIEC shows pathogenic phenotypic and genetic similarities with Shigella spp. and are associated with dysentery [24].

\section{Materials and Methods}

A total of 150 samples of milk and milk products were collected (Table 1) from Udaipur city. The samples were processed as per the standard microbiological techniques [25]. The isolation was done by selective enrichment in broth and plating on MacConkey agar (HiMedia). The lactose fermenting colonies were selected and streaked on EMB agar (HiMedia). The colonies producing metallic sheen were selected for further biochemical tests viz., indole test, methyl red test, Voges-Proskauer test, citrate test (IMViC test), TSI test and urease test.

\section{Serogrouping}

The E. coli isolates recovered from milk and milk product samples were serotyped at the National Salmonella and Escherichia Centre (NSEC), Central Research Institute (CRI), Kasauli, H. P., India. 
Polymerase chain reaction for the detection of $s t x_{1}$ and bla $_{C T X-M}$ genes

The primers used in the study are listed in Table 2 and 3. The template DNA was prepared as per the method of HiMedia TM Bacterial Genomic DNA Purification Kit.

The PCR procedure to screen the $s t x_{1}$ and $b l a_{C T X-M}$ genes were standardized as described by Hazarika et al., 2007 and Edelstein et al., 2003 with certain modifications. Followed by preliminary trials, the reaction mixtures were optimized to contain $12.5 \mu 12$ X PCR master mix (Fermentas), 10 pmol of each forward and reverse primer, $7.5 \mu 1$ nuclease free distilled water and $3 \mu \mathrm{l}$ of DNA template. The reactions were performed in the thermal cycler (Cole-Parmer) with pre-heated lid (lid temp. $=105^{\circ} \mathrm{C}$ ). The cycling conditions were comprised of an initial denaturation at $94^{\circ} \mathrm{C}$ for $4 \mathrm{~min}$ followed by 35 cycles of denaturation at $94^{\circ} \mathrm{C}$ for 30 seconds, annealing at $55^{\circ} \mathrm{C}$ for 30 seconds, extension at $72^{\circ} \mathrm{C}$ for $1 \mathrm{~min}$ and final extension at $72^{\circ} \mathrm{C}$ for $5 \mathrm{~min}$.

The amplified products were analysed by electrophoresis in $1 \%$ agarose gel containing ethidium bromide $(0.5 \mathrm{~g} / \mathrm{ml})$ along with 100 bp molecular weight DNA marker in horizontal electrophoresis unit (Tarsons). The gel was visualized under UV transilluminator (N\&M).

Antimicrobial susceptibility testing of $\boldsymbol{E}$ coli isolates

All the Escherichia coli isolates were subjected to antibiotic sensitivity test as described by Bauer et al., 1966 [28]. Antimicrobial susceptibility testing was done by agar disc diffusion method. A total of 12 antibiotic discs comprising of Ciprofloxacin, Ampicillin, Co-trimoxazole, Penicillin, Trimethoprim, Carbenicillin, Erythromycin, Chloramphenicol, Tetracycline, Methicillin,
Ceftriaxone and Gentamicin were placed on two agar plates each containing 6 antibiotic discs. The zone of inhibition was recorded to determine the susceptibility pattern of the isolates.

\section{Results and Discussion}

Prevalence of $E$. coli in milk and milk products

All the isolates which produced bright pink colonies on MacConkey agar (Fig 1) and colonies with a characteristic metallic sheen on EMB agar (Fig. 2) were selected. Further, the suspected isolates which were found positive for indole and methyl red test while negative for citrate and Voges Proskauer test were confirms as E. coli. Out of 150 samples, the prevalence of $E$. coli was recorded in raw pooled milk, dahi, paneer, pasteurized milk and sweets (burfi) samples as $76.66 \%$ (23), $33.33 \%$ (10), 20\% (6), $0 \%$ (0) and $43.33 \%$ (13), respectively.

\section{Serogroups of $E$. coli isolates}

Out of the 23 isolates, 14 isolates of E. coli were typed for ' $\mathrm{O}$ ' antigen. The 14 isolates which could be typed were distributed into 9 different serogroups, whereas 2 isolates did not reacted with the available $O$ group sera (untypable) and 7 were found to be rough. The detailed results of $E$. coli serogroups of each category are shown in Table 4.

\section{Detection of $s t x_{1}$ and $b l a_{C T X-M}$ gene of $E$. coli}

Screening of samples for the presence of $s t x_{1}$ and bla $_{C T X-M}$ gene was done by PCR (Fig $3 \&$ 4). Out of 40 E. coli isolates recovered from milk and milk products, only 2 isolates $(1.25 \%)$ were found to be positive for stxl gene. While, out of $50 \mathrm{E}$. coli isolates from milk and milk products, only 11 isolates (22\%) were found to be positive for $b l a_{C T X-M}$ 
gene. The prevalence of $E$. coli harbouringstx $x_{1}$ products is presented in Table 5. and bla $_{C T X-M}$ gene from milk and milk

Table.1 Different types samples collected for E. coli isolation

\begin{tabular}{|c|c|c|}
\hline S. No. & Type of Sample & No. of Samples \\
\hline $\mathbf{1 .}$ & Raw Pooled Milk Samples & $\mathrm{n}=30$ \\
\hline $\mathbf{2 .}$ & Pasteurized Milk Samples & $\mathrm{n}=30$ \\
\hline $\mathbf{3 .}$ & Dahi Samples & $\mathrm{n}=30$ \\
\hline $\mathbf{4 .}$ & Paneer Samples & $\mathrm{n}=30$ \\
\hline $\mathbf{5 .}$ & Sweets (Burfi) Samples & $\mathrm{n}=30$ \\
\hline & Total & $\mathrm{n}=\mathbf{1 5 0}$ \\
\hline
\end{tabular}

Table.2 The primers used for the detection of $s t x_{1}$ gene (Hazarika et al., 2007) [26]

\begin{tabular}{|c|c|c|c|c|c|}
\hline $\begin{array}{c}\text { S. } \\
\text { No. }\end{array}$ & $\begin{array}{c}\text { Oligo } \\
\text { Name }\end{array}$ & Sequence (5'->3') & $\begin{array}{c}\text { T } \\
\left({ }^{\circ} \mathbf{C}\right)\end{array}$ & $\begin{array}{c}\text { GC- } \\
\text { Content }\end{array}$ & $\begin{array}{c}\text { Size of } \\
\text { amplified } \\
\text { product (bp) }\end{array}$ \\
\hline $\mathbf{1 .}$ & Stxl F & CTGCTAATAGTTCTGCGCAC & 57.3 & $50 \%$ & $894 \mathrm{bp}$ \\
\hline $\mathbf{2 .}$ & Stxl R & CAGTTAATGTGGTGGCGAG & 56.7 & $52.6 \%$ & 894 \\
\hline
\end{tabular}

Table.3 The primers used for detection of $b l a_{C T X-M}$ gene (Edelstein et al., 2003) [27]

\begin{tabular}{|c|c|c|c|c|c|}
\hline S. No. & Oligo Name & Sequence (5'->3') & $\begin{array}{c}\text { T } \\
\left({ }^{\circ} \mathbf{C}\right)\end{array}$ & $\begin{array}{c}\text { GC- } \\
\text { Content }\end{array}$ & $\begin{array}{c}\text { Size of } \\
\text { amplified } \\
\text { product (bp) }\end{array}$ \\
\hline 1. & bla $a_{C T X-M} \mathrm{~F}$ & CGATATCGTTGGTGGTGCCATA & 60.3 & $50 \%$ & \\
\hline $\mathbf{2 .}$ & bla $a_{C T X-M} \mathrm{R}$ & TTTGCGATGTGCAGTACCAGTAA & 58.9 & $43.5 \%$ & $544 \mathrm{bp}$ \\
\hline
\end{tabular}

Table.4 The distribution of $E$. coli serogroups milk and milk products

\begin{tabular}{|c|c|c|c|c|c|}
\hline $\begin{array}{c}\text { S. } \\
\text { No. }\end{array}$ & Type of Samples & $\begin{array}{c}\text { Total No. } \\
\text { of Samples }\end{array}$ & $\begin{array}{c}\text { No. of } \\
\text { Positive } \\
\text { Isolates }\end{array}$ & Prevalence & Serogroups \\
\hline 1. & Raw Pooled Milk Samples & 30 & 23 & $76.66 \%$ & O15, O83, O8, O118, \\
& & & & & O4, O15, O7, O17 \\
\hline 2. & Pasteurized Milk Samples & 30 & 0 & Nil & - \\
\hline $\mathbf{3 .}$ & Dahi Samples & 30 & 10 & $33.33 \%$ & - \\
\hline $\mathbf{4 .}$ & Paneer Samples & 30 & 6 & $20 \%$ & - \\
\hline $\mathbf{5 .}$ & Sweets (Burfi) & 30 & 13 & $43.33 \%$ & - \\
\hline & Total & $\mathbf{1 5 0}$ & $\mathbf{5 2}$ & $\mathbf{3 4 . 6 6 \%}$ & - \\
\hline
\end{tabular}


Table.5 Prevalence of $E$. coli harbouring $s t x_{1}$ and bla $_{C T X-M}$ gene from milk and milk products

\begin{tabular}{|c|c|}
\hline Name of the gene & Positive isolate \\
\hline stx $_{\boldsymbol{1}}$ & 2 (isolate no. 64, 84) \\
\hline bla $_{C T X-M}$ & 11 (isolate no. 67, 139, 27, 33, 11, 104, 87, 62, 5, \\
& $128,9)$ \\
\hline
\end{tabular}

Table.6 Antibiotic resistance profile of the E. coli isolates from milk and milk products

\begin{tabular}{|c|c|c|c|c|c|c|c|c|c|c|c|c|c|}
\hline \multirow[t]{2}{*}{$\begin{array}{l}\mathbf{S} \\
\mathbf{N}\end{array}$} & \multirow[t]{2}{*}{ Antibiotic } & \multicolumn{3}{|c|}{$\begin{array}{c}\text { Raw Pooled Milk } \\
\text { Samples }\end{array}$} & \multicolumn{3}{|c|}{ Dahi Samples } & \multicolumn{3}{|c|}{ Paneer Samples } & \multicolumn{3}{|c|}{ Sweets (Burfi) } \\
\hline & & $\mathbf{R}(\%)$ & $I(\%)$ & $\mathbf{S}(\%)$ & $\mathbf{R}(\%)$ & $(\%)$ & S (\%) & $\mathbf{R}(\%)$ & I (\%) & S (\%) & $\mathbf{R}(\%)$ & I (\%) & S (\%) \\
\hline 1 & Peni & $0(0)$ & (0) & $100(23)$ & $23.07(3)$ & $0(0)$ & 76 & $0(0)$ & & 6) & (0) & $0(0)$ & $100(10)$ \\
\hline 2 & Gent & $\begin{array}{c}82.60 \\
(19)\end{array}$ & $13.04(3)$ & $4.34(1)$ & $100(13)$ & 0) & $0(0)$ & (6) & 1) & $0(0)$ & $0(10)$ & $0(0)$ & $0(0)$ \\
\hline 3 & ing & $82.60(19)$ & & $69(2)$ & $(1$ & & & $100(6)$ & & & 7) & $0(2)$ & $0(1)$ \\
\hline 4 & Trim & & & $13.04(3)$ & $100(13)$ & & & (5) & & & $80(8)$ & $0(0)$ & $0(2)$ \\
\hline 5 & & $30.43(7$ & & (10) & & & & $\begin{array}{c}16.66 \\
(1)\end{array}$ & & & & 1) & \\
\hline 6 & & & 1. & $\begin{array}{c}52.17 \\
(12)\end{array}$ & 30.76 (4) & $7.69(1)$ & & $0(0)$ & & & $10(1)$ & $0(0)$ & 0 (9) \\
\hline 7 & Fryth & & $(13$ & $\begin{array}{c}43.47 \\
(10)\end{array}$ & ) & 53 & & $\begin{array}{c}10.66 \\
(1)\end{array}$ & & 2) & 1) & $30(3)$ & $70(7)$ \\
\hline 8 & $\begin{array}{r}\text { Chlorat } \\
\mathrm{cc}\end{array}$ & 9 & $0(0)$ & $8.69(2)$ & 10 & & & $\begin{array}{c}83.33 \\
(5)\end{array}$ & 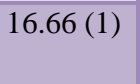 & (D) & $90(y)$ & (1) & $0(0)$ \\
\hline 9 & Tetracycline & 17 & $\begin{array}{r}0.0 \\
(14\end{array}$ & $21.73(5)$ & $7.69(1)$ & $53.84(7)$ & 38 & $\begin{array}{c}33.33 \\
(2)\end{array}$ & 2) & 2) & $0(0)$ & 70 (7) & 30 (3) \\
\hline 10 & & $8.69(2)$ & $0(0)$ & $3(21)$ & $0(0)$ & & & $0(0)$ & 0 & & 0 & $0(0)$ & $100(10)$ \\
\hline 11 & Ceftriaxor & $\begin{array}{c}78.26 \\
(18)\end{array}$ & $4.34(1)$ & $17.39(4)$ & $\begin{array}{c}84.61 \\
(11)\end{array}$ & $7.69(1)$ & 7.69(1) & $50(3)$ & $33.33(2)$ & $16.66(1)$ & $70(7)$ & $10(1)$ & $20(2)$ \\
\hline 12 & $\begin{array}{c}\text { Co- } \\
\text { Trimoxazole }\end{array}$ & $\begin{array}{l}73.91 \\
(17)\end{array}$ & $\begin{array}{c}13.04 \\
(3)\end{array}$ & $\begin{array}{l}13.04 \\
(3)\end{array}$ & $\begin{array}{l}100 \\
(13)\end{array}$ & & & $\begin{array}{l}83.33 \\
(5)\end{array}$ & & $\begin{array}{l}16.66 \\
(1)\end{array}$ & $80(8)$ & (0) & $20(2)$ \\
\hline
\end{tabular}

Fig.1 Growth on MacConkey Agar Plates

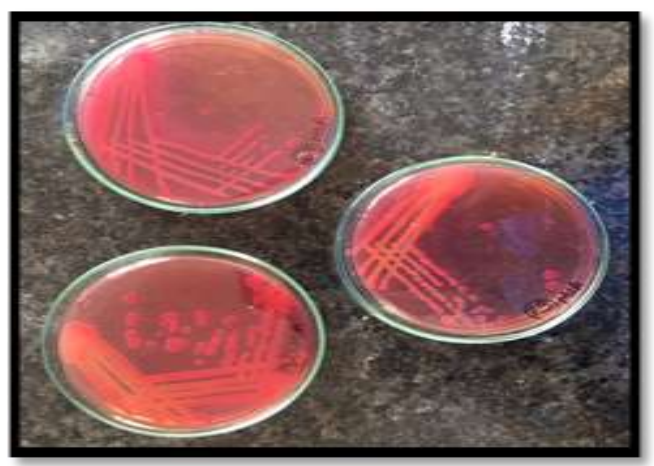


Fig.2 Growth on EMB Agar Plates

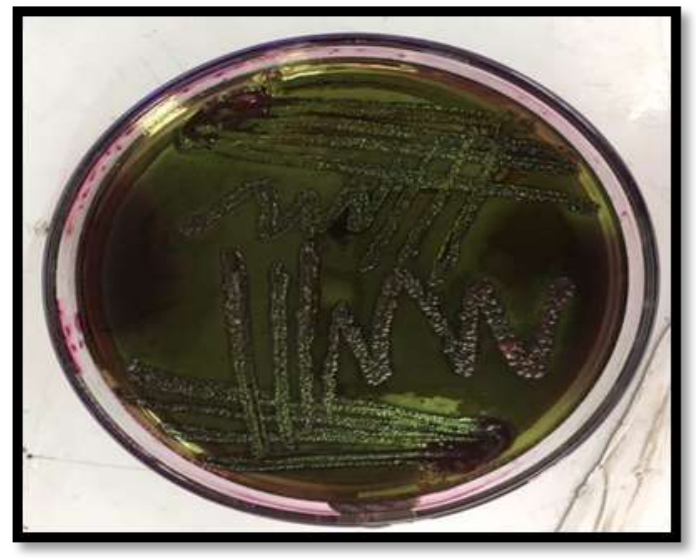

Fig.3 Agarose gel showing PCR amplified product (894 bp) for stx $x_{1}$ gene in E. coli isolates N - Negative control, L - 100 bp DNA Ladder, 64, 84 - Positive Sample

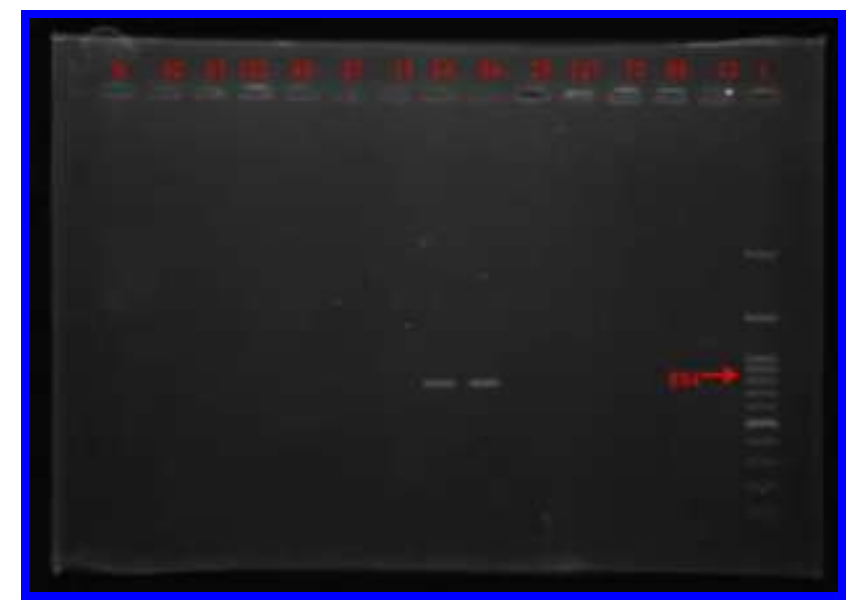

Fig.4 Agarose gel showing PCR amplified product (544 bp) for bla ${ }_{C T X-M}$ gene in $E$. coli isolates L - 100 bp DNA Ladder, Positive Samples $(33,27)$

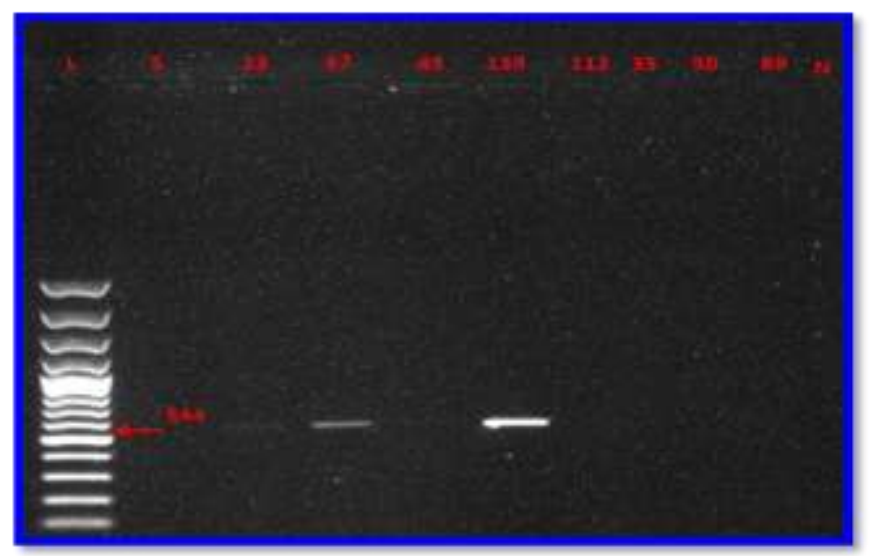


Antibiotic susceptibility pattern of $E$. coli isolates

The analysis of antibiogram revealed that the most effective antibiotic was Chloramphenicol (91.30\%), followed by Trimethoprim to which $86.95 \%$ of the isolates were sensitive. Also, $82.60 \%$ isolates were sensitive to Gentamicin and Ciprofloxacin, $78.26 \%$ to Ceftriaxone, $73.91 \%$ to Co-Trimoxazole and other antibiotics were still less effective. Penicillin$\mathrm{G}$ showed highest resistance (100.00\%) followed by Methicillin (91.30\%), while $52.17 \%$ isolates were resistant to Ampicillin, 43.47\% to Erythromycin and Carbenicillin, $21.73 \%$ to Tetracycline and other antibiotics were still less resistant. The antibiotic resistance profile of the E. coli isolates from milk and milk products is shown in Table 6.

\section{References}

Oliver, S.P., Jayarao, B.M. and Almeida, R.A. (2005) Foodborne pathogens in milk and the dairy farm environment: food safety and public health implications. Foodborne Pathogens and Disease, 2(2): 115-129.

Laba, S.A. and Udosek, C.E. (2013) Bacteriological quality of raw cow milk in Ilorin, north central Nigeria. Nat. Sci., 11(10): 73-79.

Garedew, L., Berhanu, A., Mengesha, D. and Tsegay, G. (2012) Identification of gram-negative bacteria from critical control points of raw and pasteurized cow milk consumed at Gondar town and its suburbs, Ethiopia. BMC Public Health, 12: 950.

Ahmed, A. and Shimamoto, T. (2014) Isolation and molecular characterization of Salmonella enterica, Escherichia coli O157:H7 and Shigella spp. from meat and dairy products in Egypt. Int $J$ Food Microbiol,168-169; 57-62.
EFSA-ECDC. (2015) The European Union summary report on trends and sources of zoonoses, zoonotic agents and foodborne outbreaks in 2013. EFSA J. 13: 3991-4156.

Oliver, S.P., Boor, K.J., Murphy, S.C. and Murinda, S.E. (2009) Food safety hazards associated with consumption of raw milk. Foodborne Pathogens and Disease, 6(7): 793-806.

WHO, (2004) "A response to the need for comprehensive, consistent and comparable information on diseases and injuries at global and regional level." The Global Burden of Disease. World Health Organization.

Rehman, M.U., Rashid, M., Sheikh, J.A. annd Bhat, M.A. (2014) Molecular epidemiology and antibiotic resistance pattern of enteropathogenic Escherichia coli isolated from bovines and their handlers in Jammu. India. $J$. Adv. Vet. Anim. Res., 1(4): 177-181.

Gould, L.H., Walsh, K.A., Vieira, A.R., Herman, K., Williams, I.T. and Hall, A.J. (2013) Surveillance for foodborne disease outbreaks-United States, 1998-2008. MMWR SurveillSumm, 62(2): 1-34.

Havelaar, A.H., Kirk, M.D., Torgerson, P.R., Gibb, H.J., Hald, T. and Lake, R.J. (2015) World Health Organization Global Estimates and Regional Comparisons of the Burden of Foodborne Disease in 2010. PLoS Med.,12(12).

Scallan, E., Hoekstra, R.M., Angulo, F.J., Tauxe, R.V., Widdowson, M.A. and Roy, S.L. (2011) Foodborne Illness Acquired in the United States-Major Pathogens. Emerg Infect Dis., 17(1): $7-15$.

Momtaz, H., Karimian, A., Madani, M., SafarpoorDehkordi, F., Ranjbar, R. and Sarshar, M. (2013) Uropathogenic Escherichia coli in Iran: Serogroup 
distributions, virulence factors and antimicrobial resistance properties. Ann Clin MicrobiolAntimicrob., 12(1):8.

Christidis, T., Pintar, K.D., Butler, A.J., Nesbitt, A., Thomas, M.K., Marshall, B. and Pollari, F. (2016) Campylobacter spp. Prevalence and Levels in Raw Milk: A Systematic Review and Meta-Analysis. J. Food Prot., 79(10): 1775-1783.

Selim, S., Ahmed, S., Abdel Aziz, M., Zakaria, A., Klena, J. and Pangallo, D. (2013) Prevalence and characterization of Shiga-toxin O157:H7 and nonO157:H7 enterohemorrhagic Escherichia coli isolated from different sources. Biotechnol. Biotechnol Equip, 27: 3834-3842.

Soomro, A., Arain, M., Khaskheli, M. and Bhutto, B. (2002) Isolation of Escherichia coli from raw milk and milk products in relation to public health sold under market condition at Tandojam. Pakistan Journal of Nutrition, 13: 151-152.

Servin, A.L. (2014) Pathogenesis of human diffusely adhering Escherichia coli expressing Afa/Dr adhesins (Afa/Dr DAEC): Current insights and future challenges. Clin. Microbiol., 27: 823869.

Álvarez-Suárez, M.E., Otero, A., GarcíaLópez, M.L., Dahbi, G., Blanco, M. and Mora, A. (2016) Genetic characterization of Shiga toxin producing Escherichia coli (STEC) and atypical enteropathogenic Escherichia coli (EPEC) isolates from goat's milk and goat farm environment. Int J Food Microbiol., 236: 148-154.

Momtaz, H, Farzan, R., Rahimi, E., SafarpoorDehkordi, F. and Souod, N. (2012) Molecular Characterization of ShigaToxin-Producing Escherichia coli Isolated from Ruminant and
Donkey Raw Milk Samples and Traditional Dairy Products in Iran. Sci World J., 2012: 1-13.

Dehkordi, F., Yazdani, F., Mozafari, J. and Valizadeh, Y. (2014) Virulence factors, serogroups and antimicrobial resistance properties of Escherichia coli strains in fermented dairy products. BMC Res Notes, 7(1): 217.

Hiraka, T., Kanoto, M., Sugai, Y., Honma, T., Makino, N., Ueno, Y. and Hosoya, T. (2015) Computed tomographic findings of enterohemorrhagic Escherichia coli 0157 infection: An analysis of a 7-case regional outbreak. J. Comput. Assist. Tomo., 39(3): 406408.

Garbaj, A.M., Awad, E.M., Azwai, S.M., Abolghait, S.K., Naas, H.T., Moawad, A.A. and Eldaghayes, I.M. (2016) Enterohemorrhagic Escherichia coli O157 in milk and dairy products from Libya: Isolation and molecular identification by partial sequencing of 16S rDNA. Vet. World, 9(11): 1184.

Viazis, S. and Diez-Gonzalez, F. (2011) In the Twentieth Century's Emerging Foodborne Pathogen: A Review. Elsevier, New York, NY, USA, 111.

Jafari, A., Aslani, M.M. and Bouzari, S. (2012) A brief review of diarrheagenic pathotypes and their role in diarrheal diseases in Iran. Iran. J. Microbiol., 4: 102-117.

Karmali, M.A., Gannon, V. and Sargeant, J.M. (2010) Verocytotoxin-producing Escherichia coli (VTEC). Vet. Microbiol. 140: 360-370.

Quinn, P.J., Carter, M.E., Markey, B.K. and Carter, G.R (1994) Clinical Veterinary Microbiology, pp. 21-26 and 209-236.

Hazarika, R.A., Singh, D.K., Kapoor, K.N., Agrawal, R.K., Pandey, A.B. and Purosottam. (2007) Verotoxigenic Escherchia coli (STEC) from beef and 
its products. Indian Journal of Experimental Biology, 45: 207-211.

Edelstein, M., Pimkin, M., Palagin, I., Edelstein, I. and Stratchounski, L. (2003) Prevalence and molecular epidemiology of CTX-M extendedspectrum $\quad \beta$-lactamase-producing Escherichia coli and Klebsiella pneumonia in Russian hospitals. Antimicrob Agents Chemother. 47: 3724-32.

Bauer, A.W., Kirby, W.M.M., Sherris, J.C. and Turck, M. (1966) Antibiotic susceptibility testing by a standardized single disc method. Am J. Clin. Pathol., 45(4): 493-496.

\section{How to cite this article:}

Monika Soni, Abhishek Gaurav, Bincy Joseph, S. S. Shekhawat and Subhash Chand Meena. 2019. Prevalence and Drug Resistance Pattern of Escherichia coli Strains Isolated from Milk and Milk Products. Int.J.Curr.Microbiol.App.Sci. 8(10): 1338-1346.

doi: https://doi.org/10.20546/ijcmas.2019.810.156 